\title{
Amin Karimnia
}

Fasa Branch, Islamic Azad University, Iran

Mahmood Khosravani

Torbat-e Heydarieh Branch, Islamic Azad University, Iran

\section{A COMPARATIVE STUDY OF FORM-FOCUSED AND COMMUNICATIVE METHODS OF LANGUAGE TEACHING IN ESP COURSES}

Summary. The purpose of this study was to compare the effectiveness of the use of communicative methods and form-focused methods as implemented in English for Specific Purposes (ESP) courses. To accomplish this, two groups of management students were selected for the study. Each group consisted of 30 participants. Their level of proficiency in English and their subject matter knowledge were tested through a sample of IELTS and a pre-test. The two groups were at the same level of proficiency in both general English and English for Students of Management before receiving treatment in 20 sessions within a period of 75 days. Participants in Group A received a form-focused method with some occasional uses of their L1. In Group B, however, the participants were exposed to a communicative ESP course which exclusively relied on English the L2. After the period of treatment, the two groups were examined via a post-test. Results showed that Group B was more successful in the post-test. Moreover, the learners who were proficient in English and the subject matter achieved more from the communicative methods of language teaching in the ESP course. Findings imply that the nature of the subject matter, or whether it is theoretical or applied, could be a factor in deciding a method of language teaching for ESP courses.

Keywords: second language teaching/learning; communicative methods; formfocused methods; IELTS; ESP.

\section{Introduction}

English for Specific Purposes (ESP) is a method of language teaching in which the practical needs (e.g. occupational or academic) of a group of learners shape the primary focus of the course. ESP, as a general term, may be used to refer to English for Academic Purposes (EAP) and to English for Occupational Purposes (EOP). Yet, in the literature on L2 teaching, as it is the case in this study, ESP can terminologically apply to both of these sub-types. The most important aspect of an ESP context, no matter how it is implemented, is to meet the specific needs of learners. Naturally, various philosophies and methodologies of L2 teaching can help formulate ESP courses. 
A central question that demands rigorous research is the way ESP should be configured. Communicative methods of language teaching and formfocused methods can contribute to the application of teaching methods in ESP courses, although in practice these two methods differently approach the process of teaching. Communicative methods normally rest on the fundamental idea that L1 and L2 are in some ways equal (the L1=L2 hypothesis) (Nation, 2005). Some researchers (Macaro, 2009; Rivers, 2011; Karimnia \& Izadparast, 2007) have indicated that the native language of L2 learners cannot be fully excluded from L2 classrooms. In contrast, some other studies (Davila, 2005; Tang, 2002) claimed that full exposure to L2 is not the ultimate purpose of learning a new language.

The usage of $L 1$ as a vehicle for transferring information and a means of interaction has been a popular topic for investigation among EFL and ESP teachers. Some argue that L1 can help the process of teaching/learning when properly employed. On the other hand, some researchers have insisted that prohibiting the use of L1 would not be conducive to the process, particularly in ESP courses (Dujmovic, 2007). Whether or not the focus on form, accompanied by occasional uses of L1, can contribute to ESP courses is a matter that demands further investigation.

This study seeks to make a comparison between communicative methods of language teaching and form-focused language teaching in ESP courses. These two methods of language teaching have been widely studied in the history of language teaching. However, their effectiveness in ESP courses has not been properly examined in these research projects. This study investigates an empirical context in which two groups of management students received two different teaching treatments (communicative and form-focused). The study, more specifically, tries to answer the question which method may better serve ESP courses and to explore further the conditions that cause the more effective method.

\section{Literature Review}

In the literature on ESP, the majority of research projects have focused on ESP textbooks, learners' needs, and learners' attitudes. Therefore, the role of 
teaching methods and the languages used in ESP have not been rigorously explored. Khoshsima and Khosravani (2014) reported that Iranian ESP teachers did not express positive attitudes about the teaching methods employed in ESP courses and textbooks. They believed some fundamental corrections had to be implemented to render these courses more effective.

A number of studies have revealed that using L1 in ESP courses could be helpful (see Khresheh, 2012; Jafari \& Shokrpour, 2013; Mart, 2013). These findings, however, have been interpreted as challenges to the consistency of communicative methods of language teaching with ESP courses. Jamshidi and Naveebrahimi (2013) found that the use of Persian (L1) had a positive impact on learners' confidence in English classrooms. Similarly, L2 learners who interact in their native language are likely to be more encouraged in ESP classes (Spahiu, 2013). Of course, McMillan and Rivers (2011) argued that in order to benefit from L1 in communication, L1 must be selectively and appropriately employed.

Khati (2011) conducted a study on the use of L1 in English classes, which presented a method in clash with the rationale of communicative methods. The study found that L1 used in English classes contributed to the learners' progress. Another study confirmed that English words/definitions, supplemented by their Persian (L1) equivalents, could leave a positive effect on the learning of the new lexical items and enhanced the leaners' word power (Afzal, 2013).

Nonetheless, Cook (2001) contends that L1 and L2 rest on two different linguistic systems with specific features. As a result, learners should limit their reliance on L1 and interact communicatively to accomplish their objectives in L2 learning. Learners need maximum exposure to $L 2$ to learn it in the most effective way. Mattioli (2004, cited in Davila, 2005) similarly asserts that the use of L1 is not effective, and that even grammatical points should be explained in English.

Ghanbari and Eslami-Rasekh (2010) emphasize that learners' needs are the most important priority in ESP courses. Despite this obvious fact, the authors explain that ESP courses in Iran are not designed based on any systematic needs analysis framework. Maleki (2006) investigated the effectiveness of ESP courses by comparing the courses held by an EFL 
teacher and a subject matter specialist. Davoudi-Mobarakeh, Eslami-Rasekh, and Barati (2014) observed that the majority of ESP courses which are taught by content specialists are ineffective. They pointed out several shortcomings that made such ESP courses ineffective, such as a lack of variety of pedagogical techniques, a lack of background knowledge about strategies and methodologies, and a lack of linguistic knowledge to teach English.

Focus on form can be either explicit or implicit in teaching grammatical points. Of course, explicitness and implicitness fall within a range of options. On the one hand, the course may exclusively focus on providing metalinguistic explanations about grammatical points. On the other, no metalinguistic explanation may be provided about grammatical points. Between these two extremes, there is a wide range of possibilities which may explore various aspects of forms. There are some techniques that can be used to focus on forms in language teaching classrooms, including "recast", "input enhancement", and "consciousness-raising tasks". Through recasting, "the teacher reformulates what the student has said or written incorrectly in a more accurate, meaningful, or appropriate manner" (Celce-Murcia, 2001, p. 257). Recasting can help the learner to figure out a grammatical point. Consciousness-raising tasks involve a learner's induction of a grammatical form explicitly presented. According to Lyster (1998), among the techniques that focus on form, explicit techniques are more effective and bring about better results. Karbalaei, Pourzargham and Kazemi (2013) explored the role of formfocused instructions, observing that focus on form through visual media could enhance grammar, vocabulary and reading comprehension.

English language teaching scholars (e.g., Ellis, 2006) have always tried to develop or draw on the best and most effective way of teaching grammatical points. To date, many different methods and approaches have been practiced. A common assumption is that knowledge of grammar may be of two types, namely explicit and implicit. According to Ellis (2005), these two types of knowledge are different from each other and are represented in of the brain separated from each other. Further, Ellis (2006) enumerates three criteria that can be used to distinguish explicit and implicit grammar knowledge. These criteria include level of awareness, accessibility, and knowledge verbalization. The distinction between explicit and implicit Form-Focused Instruction (FFI) 
could be considered in relation to another common distinction-isolated versus integrative FFI (Lightbown \& Spada, 1990).

Recently, a large body of research projects and reviews on second language acquisition (SLA) research have demonstrated that FFI can potentially help learners to develop their awareness of L2 (Spada, 2006). Long (1991) distinguished "focus-on-forms" from "focus-on-form" instruction. Focus-on-forms is evident in the traditional approach to grammar teaching based on a synthetic syllabus. The underlying assumption is that language learning is a process of accumulating distinct entities. In such an approach, learners are required to treat language primarily as an "object" of study that is practiced bit by bit. In other words, learners function as "students" rather than as "users" of the language (Ellis, 2006). On the other hand, focus-on-form "draws students' attention to linguistic elements as they arise incidentally in lessons whose overriding focus is on meaning or communication" (Long, 1991, pp. 45-46). According to Long and Robinson (1998), such an approach is to be distinguished not only from focus-on-form but also from focus-on-meaning.

The aim of this study was to compare the effectiveness of form-focused language teaching and communicative methods in ESP courses. To accomplish this, two groups of learners were taught by these methods in order to find which one is more effective in ESP courses. In the communicative method, meaning is emphasized, and English (L2) is the only vehicle for explaining the content of the course. In form-focused instruction, in contrast, grammatical structures are the main focus of instruction and L1 of is used in some occasions to explain the content of the course.

\section{Method}

\section{Participants}

Participants of this study were selected from among students of Management at Chabahar Maritime University, Iran. They were classified into two groups, each one consisting of 30 participants. Group A included 17 males and 13 females, and Group B consisted of 18 males and 12 females. These participants were aged 20-24. The general English proficiency of these participants was tested by a sample of IELTS test. This test was used to make 
sure that the two groups were at the same level of proficiency in general English. The Participants had not passed any ESP course in management before this study was conducted.

\section{Materials}

In this study, a pre-test and a post-test were used to examine the participants' proficiency in English for Students of Management. These tests, which were formulated as multiple-choice questions, were designed by the researchers of the study. The pre-test and post-test shared the same design. The aim of the first section was to examine the participants' knowledge of technical terms in management. The second section, however, examined the participants' proficiency in grammar. Although the main purpose of the second part was to verify grammatical proficiency, the participants had to have knowledge of technical terms in management to perform well. The third section consisted of two reading comprehension texts. Each part consisted of a passage about management followed by 5 multiple-choice questions. Totally, each test consisted of 15 questions for testing vocabulary, 15 questions for testing grammatical knowledge in special texts of management, and 10 questions for testing the participants' proficiency in understanding special texts in management.

\section{Procedure}

Primarily, a sample of IELTS was administered to make sure that the participants were at the same level of proficiency in general English and English for Students of Management. Both groups of participants were taught by the same instructor. However, the two groups were exposed to different methods. In Group A, the instructor relied on a form-focused method to teach the content of the course. He used both English and Persian to explain grammatical structures. Persian equivalents of technical vocabulary terms were also used to explain the meanings of the words. He also used Persian to elaborate on reading passages. 
In Group B, however, the instructor used only a communicative method to teach the content of the course. Even the meanings of special vocabulary and grammatical points were explained in English. The two classes were taught throughout a period of three months, with two sessions held every week. After this period of treatment, both language proficiency levels were examined through the post-test.

\section{Data analysis}

The data gathered in this study were statistically analyzed using SPSS. The means of scores of both groups in the pre-test and post-test were calculated. Additionally, two t-tests were also conducted. The purpose of the first t-test was to compare the proficiency level of the participants before the treatment. The second t-test, however, was to compare the performance of the two groups after the treatment. The obtained means and $p$-values could serve as a criterion for comparing the progress of the two groups which were exposed to two different methods (form-focused and communicative) within an ESP-based framework.

\section{Findings and Result}

A t-test, as mentioned earlier, was used to compare the scores of the two groups in the pre-test (see Table 1 for results). The obtained $p$-value in this test was 0.9654, which was not statistically significant. This value and the means of the two groups revealed that there was no significant difference between the participants' scores on the pre-test. In other words, the two groups were almost at the same level of proficiency before the treatment of the two different methods.

Table 1.

Results of the first t-test

\begin{tabular}{|l|c|c|c|c|c|}
\hline - & Mean & SD & SEM & N & P-value \\
\hline Group A (Form-focused) & 22.28 & 4.73 & 1.23 & 30 & 0.9654 \\
\hline
\end{tabular}




\begin{tabular}{|l|c|c|c|c|c|}
\hline- & Mean & SD & SEM & N & P-value \\
\hline Group B (Communicative) & 22.76 & 5.66 & 1.54 & 30 & \\
\hline
\end{tabular}

The second t-test was conducted to compare the participants' scores on the post-test (see Table 2).

Table 2.

Results of the second t-test

\begin{tabular}{|l|c|c|c|c|c|}
\hline- & Mean & SD & SEM & N & P-value \\
\hline Group A & 22.28 & 5.13 & 1.43 & 30 & \\
\hline Group B & 25.80 & 4.98 & 1.66 & 30 & 0.1243 \\
\hline
\end{tabular}

The obtained means and p-value (0.1243) clarified that there was no significant difference between the performances of the two groups. Although the $p$-value was not less than 0.05 , it could still point to a difference. In other words, the performance of Group $B$, which received the teaching using a communicative method, was relatively better than the performance of Group A, which was taught through the form-focused method. As can be seen in Table 2, the mean of scores of Ggroup B was higher than of Group A.

\section{Discussion}

The results obtained in this study suggest that employing communicative methods of language teaching in ESP classrooms help learners' improve their L2 proficiency more successfully. In most ESP courses, learners normally possess rich background knowledge of the subject matter they study. This knowledge is critical for the success of $L 2$ learners. In fact, in the majority of cases, learners are completely familiar with the content of the course. Relying on this thematic background knowledge, learners can make inferences and easily distinguish problematic issues. In cases where learners are not knowledgeable enough in English to understand some parts of the specific content, they may rely on their background knowledge of the subject matter 
to fill the gap. This is critically important in two respects. First, this strategy helps learners to receive a higher amount of input. In such cases, learners tend to compensate their insufficient knowledge in specialized English by activating their technical knowledge of the subject matter. In fact, learning can be seen as a dynamic process that can be facilitated by recourse to a variety of resources, including knowledge of English and knowledge of the subject matter. When one of these available resources is insufficient, the other resources can be adopted. This process of learning and receiving input continues throughout the course. Receiving increased input could lead to expanded learning. Therefore, when the content of the ESP course is taught in English without using L1, learners can enjoy a better chance of receiving a larger body of original input that can be internalized by relying on a variety of resources.

Secondly, the process of learning by receiving input from a variety of resources can be very motivating for learners. In fact, it can function as a psychologically positive force to motivate learners. When one resource is not sufficient to help learners, another one comes into action. Therefore, learning through a number of channels can be beneficial from both cognitive and psychological perspectives. However, one important point that should not be overlooked here is that learners who attend ESP courses usually possess unequal levels of knowledge both in the subject matter and English. There is no doubt that thematic knowledge can be effectively used to fill the gaps of knowledge in English. As the participants of this study were at a relatively high level of proficiency in English and management, they tended to achieve more in the communicative course (Group B), in which focus-on-forms was not a concern. Therefore, the inconsistency between the results obtained in this study and those of studies that found different results (such as Jamshidi \& Navehebrahimi, 2013; Spahiu, 2013) can be explained by learners' differences in levels of technical knowledge and English proficiency. The results of this study imply that when learners possess a high level of knowledge in the subject matter and English proficiency, they may benefit more from communicative methods of language teaching in ESP.

Another issue is that the nature (theoretical or applied) of the subject matter can have a significant influence on the success of the ESP courses. As a result, any conclusion drawn from such studies must be subjected to caution. 
Moreover, the skills that are emphasized in an ESP course are issues that cannot be ignored when we conduct such studies. Generally, in selecting a method of L2 teaching for an ESP course, a variety of factors must be considered. Every ESP course involves specific features for specific learners. The level of knowledge in English, level of knowledge in the subject matter, the nature of the subject (theoretical or applied), the skills that are the focus of the course, the length of the course, expectations of learners and the society, local conditions, and specific needs of learners are the characteristics that must be considered in formulating objectives of the ESP courses.

\section{Conclusion}

An ESP course is designed in its specific setting for a specific subject matter and learners. Learners could be at various levels of proficiency in English (L2). Based on the results obtained in this study, advanced learners would benefit more from ESP courses in which a communicative method is employed to present the materials. Therefore, course designers and planners can primarily evaluate learners' proficiency in general English. This initial evaluation can help course designers to choose the best method that suits the needs of the learners. Furthermore, the nature of the subject matter addressed in an ESP course might be different from other courses. Some subjects are theoretical and others are applied. The extent to which an ESP course explores abstract concepts, for instance, represents a critical concern because these concepts are usually difficult to explain in L2. This is particularly the case with learners who are not at an advanced level of proficiency in general English. Broadly speaking, in the process of planning for an ESP course, all of these elements must be included because the exclusion of even one element might reduce the quality of the course in question.

\section{References}

Afzal, S. (2013). Using of the first language in English classroom as a way of scaffolding for both the students and teachers to learn and teach 
English. International Research Journal of Applied and Basic Sciences, $4(7), 1846-1854$.

Celce-Murcia, M. (2001). Teaching English as a second or foreign Language. Thomson Learning Inc.

Cook, V. (2001). Using the first language in the classroom. Canadian Modern Language Review, 57(3), 402-423.

Davila, S. L. (2005). Tips and Techniques for the English Only Classroom. Retrieved from http://www.saradavila.com/english/english.doc.

Davoudi-Mobarakeh, S., Eslami-Rasekh, A., \& Barati, H. (2014). Observation and feedback of content specialists versus general English teachers: suggestions to make optimal English for specific purpose courses. Journal of English Language Teaching and Learning, 13.

Dujmovic, M. (2007). The use of Croatian in the EFL classroom. Metodicki Obzori, 2(1), 91-100. Retrieved from http://hrcak.srce.hr/file/19437.

Ellis, N. C. (2005). At the interface: Dynamic interactions of explicit and implicit language knowledge. Studies in Second Language Acquisition, 27, 305-352.

Ellis, R. (2006). Current issues in the teaching of grammar: An SLA perspective. TESOL Quarterly, 40, 83-107.

Ghanbari, B., \& Eslami Rasekh, A. (2012). ESP practitioner professionalization through apprenticeship of practice: the case of two Iranian ESP practitioners. English Language Teaching, 5, 112-122.

Jafari, S. M., \& Shokrpour, N. (2013). The role of L1 in ESP classrooms: A triangulated approach. International Journal of English and Education, 2(3), 90-104.

Jamshidi, A., \& Navehebrahim, M. (2013). Learners use of code switching in the English as a foreign language classroom. Australian Journal of Basic and Applied Sciences, 7(1), 186-190.

Karbalaei, A, Pourzargham, A., \& Kazemi, M. (2013). The impact of focus on form instruction on second language vocabulary and grammar learning. Journal of Advances in English Language Teaching, 1(1), 3138.

Karimnia, A., \& Izadparast, M. (2007). On Communicative and linguistic competence. International Journal of Communication, 17(1), 101-112. 
Khati, A. (2011). When and why of mother tongue use in English classrooms. Journal of NELTA, 16(1-2), 42-51.

Khoshsima, H., \& Khosravani, M. (2014). ESP textbooks criteria: A case study of Iranian Universities. International Journal on Studies in English Language and Literature, 2347-3134.

Khoshsima, H., Saed, A., \& Ghassemi, P. (2014). The application of ESP principles on course design: the case of English for students of Management and Fisheries. International Journal of Language Learning and Applied Linguistics World, 2289-2737.

Khresheh, A. (2012). Exploring when and why to use Arabic in the Saudi Arabian EFL classroom: Viewing L1 use as eclectic technique. English Language Teaching, 5(6), 78-88.

Lightbown, P. M., \& Spada, N. (1990). Focus-on-form and corrective feedback in communicative language teaching: Effects on second language learning. Studies in Second Language Acquisition, 12, 429-448.

Long, M. H. (1991). Focus on form: A design feature in language teaching methodology. In K. de Bot, R. Ginsberg \& C. Kramsch (Eds.), Foreign language research in crosscultural perspective (pp. 39-52). Amsterdam: John Benjamins.

Long, M. H., \& Robinson, P. (1998). Focus on form: Theory, research, and practice. In C. Doughty \& J. Williams (Eds.), Focus on form in classroom second language acquisition, (pp. 15-41). Cambridge: Cambridge University Press.

Lyster, R. (1998). Negotiation of form, recasts, and explicit correction in relation to error types and learner repair in immersion classrooms. Language Learning, 48,183-218.

Macaro, E. (2009). Teacher Use of Code-switching in the Second Language Classroom: Exploring "Optimal" Use. In: Turnbull, M., Dailey-O'Cain, J. (Eds.), First Language Use in Second and Foreign Language Learning, Bristol, (pp. 35-49). Great Britain: MPG Books Group.

Maleki, A. (2006). ESP teaching: A matter of controversy. Oxford: Oxford University Press. 
Mart, C. T. (2013). The facilitating role of L1 in ESL classes. International Journal of Academic Research in Business and Social Sciences, 3(1), 9-14. Retrieved from www.hrmars.com/journals.

Mattioli, G. (2004). On native language intrusions and making do with words: Linguistically homogeneous classrooms and native language use. English Teaching Forum, 42(4), 20-25.

McMillan, B. A., \& Rivers, D. J. (2011). The practice of policy: Teacher attitudes toward "English only". System, 39, 251-263.

Nation, I. S. P. (2005). Teaching and Learning Vocabulary. In: Hinkel, E. (Ed.), Handbook of Research in Second Language Teaching and Learning, (pp. 581-595). Lawrence Erlbaum, Mahwah, N.J.

Rivers, D. J. (2011a). Politics without pedagogy: Questioning linguistic exclusion. ELT Journal, 65(2), 103-113.

Rivers, D. J. (2011b). Strategies and struggles in the ELT classroom: Language policy, learner autonomy and innovative practice. Language Awareness, 20(1), 31-43.

Spada, N. (2006). Communicative language teaching: Current status and future prospects. In J. Cummins \& C. Davis (Eds.), The international handbook of English language teaching. Norwell, MA: Springer.

Spahiu, I. (2013). Using native language in ESL classroom. IJ-ELTS: International Journal of English Language \& Translation Studies, 1(2), 243-248. Retrieved from www.eltsjournal.org.

Tang, J. (2002). Using L1 in the English classroom. English Teaching Forum, $40(1), 36-43$. 


\section{Amin Karimnia \\ Islamiškojo Azado universiteto Fasos filialas, Iranas; \\ aminkarimnia@yahoo.com}

\section{Mahmood Khosravani}

Islamiškojo Azado universiteto Torbat-e Heydarieh filialas, Iranas;

nasirpour13@yahoo.com

\section{FORMA ORIENTUOTU IR KOMUNIKACINIU METODU, NAUDOJAMU ANGLU KALBOS SPECIALIESIEMS TIKSLAMS (ESP) KURSUOSE, LYGINAMASIS TYRIMAS}

Santrauka. Šio tyrimo tikslas yra palyginti i forma orientuotu ir komunikaciniu metodu, naudojamy angly kalbos specialiesiems tikslams (ESP) kursuose, efektyvuma. Siekiant igyvendinti ši tiksla tyrimui buvo atrinktos dvi vadyba studijuojančiu studentu grupès, kuriu kiekvienoje - po 30 dalyviu. Ju anglu kalbos lygis ir dalyko išmanymas buvo patikrinti IELTS ir preliminaraus egzaminu metu. Abi grupès turejo ta pati bendrosios anglu kalbos ir verslo anglu kalbos žiniu lygi prieš pradedant mokymo kursus, kuriu trukmè - 75 dienos. Per ši laikotarpi ivyko 20 susitikimu. Su A grupe buvo dirbama i forma orientuotu metodu, o kursu metu kartais vartojama ju gimtoji kalba. B grupès dalyviai mokèsi komunikacinio anglu kalbos specialiesiems tikslams dalyko, kuris išimtinai buvo dėstomas tik anglu kalba. Po kursu abi grupès laikè baigiamaji testa. Rezultatai parodè, kad B grupè atliko testa daug sèkmingiau. Taip pat dalyviai, kurie turejjo aukšta anglu kalbos ir dalyko išmanymo lygi, pasiekè daugiau besimokant komunikaciniu anglu kalbos specialiems tikslams mokymo metodu. Rezultatai parodè, jog dalyko pobūdis ir, ar jis yra teorinis, ar taikomasis, gali turèti reikšmès nustatant anglu kalbos specialiesiems tikslams mokymo metoda.

Pagrindinès sąvokos: antrosios kalbos mokymas/mokymasis; komunikaciniai metodai; i formą orientuoti metodai; IELTS; ESP. 